\title{
Isolation and characterization of a lectin from Andira anthelmia seeds
}

\author{
Cleane Moreira ${ }^{1 *}$, Mayara Silva ${ }^{1}$, Camila Nobre ${ }^{2}$, Thaiz Miguel', Antonia Nascimento ${ }^{1}$, Celso Nagano ${ }^{1}$, \\ Kyria Nascimento ${ }^{1}$, Benildo Cavada', Ivanice Silva ${ }^{1}$ \\ From 5th Congress of the Brazilian Biotechnology Society (SBBIOTEC) \\ Florianópolis, Brazil. 10-14 November 2013
}

Andira anthelmia seeds, a species belonging to the Leguminosae family, Papilionoideae subfamily, Dalbergieae tribe, have a glucose/mannose specific lectin that agglutinates rabbit erythrocytes treated with trypsin. The Dalbergieae tribe has lectins which have specificity for different carbohydrates including mannose and also have several biological activities such as induction of rat paw edema, release of chemotactic mediators by macrophages, vasorelaxant effect in rat aortas, termiticide activity, potential fungicide action, among others. This study aimed to isolate, purify and physicochemically characterize a lectin found in seeds of Andira anthelmia. The lectin from Andira anthelmia seeds was purified by affinity chromatography on Mannose-Sepharose matrix followed by ion exchange chromatography on DEAE-Sephacel matrix. This procedure resulted in a purified lectin, named AAL. AAL purification process was monitored by specific hemagglutinating activity and SDS-PAGE, in which it was observed that this lectin has a molecular weight of approximately $20 \mathrm{kDa}$ and four others subunits of approximately 15 and $14 \mathrm{kDa}$. This lectin is a glycoprotein with approximately $1.89 \%$ of carbohydrates on its composition and shows high stability, being able to maintain their hemagglutinating activity in a wide $\mathrm{pH}$ range and after exposure to temperatures of $70{ }^{\circ} \mathrm{C}$ for one hour. After dialysis against the chelating agent EDTA, AAL lost its hemagglutinating activity, but recovered its action after the addition of metals, being, therefore, dependent on divalent metal cations. In this study a new lectin from Dalbergieae was purified and characterized. Further analyzes are needed in order to best evaluate their biotechnological applications.

'Universidade Federal do Ceará, Fortaleza, CE, Brazil

Full list of author information is available at the end of the article
Authors' details

${ }^{1}$ Universidade Federal do Ceará, Fortaleza, CE, Brazil. ${ }^{2}$ Universidade Regional do Cariri, Crato, CE, Brazil.

Published: 1 October 2014

doi:10.1186/1753-6561-8-S4-P238

Cite this article as: Moreira et al: Isolation and characterization of a lectin from Andira anthelmia seeds. BMC Proceedings 2014 8(Suppl 4):P238.

Submit your next manuscript to BioMed Central and take full advantage of:

- Convenient online submission

- Thorough peer review

- No space constraints or color figure charges

- Immediate publication on acceptance

- Inclusion in PubMed, CAS, Scopus and Google Scholar

- Research which is freely available for redistribution 